\title{
Pengembangan Modul IPBA Materi Sistem Bumi-Bulan Berbasis Integrasi Sains-Islam
}

\author{
Dinar Maftukh Fajar ${ }^{1 *}$, Muhammad Habibbulloh ${ }^{2}$ \\ ${ }^{1}$ Program Studi Tadris IP A, Institut Agama Islam Negeri Jember \\ ${ }^{2}$ Program Studi Pendidikan IPA, Universitas Islam Lamongan \\ *Correspondence Address: dinarmaftukh@iain-jember.ac.id
}

\begin{abstract}
This paper aims to describe the development of the IPBA module on the Earth-Moon System material based on science-Islam integration for preservice science teachers in PTKI. The development procedure is carried out by adopting the $4 \mathrm{D}$ model (define, design, develop, dan diseminate) by Thiagarajan in which stage disseminate was not executed. The study involved 87 preservice science teachers in one of the PTKI. This research produces the following instructional module indicators: by analyzing the kauniyah verses and authentic hadith, students are able to (1) provide factual and actual information about the condition of the Moon as Earth's satellite; (2) analyze the relative motion of the Moon and its phases; (3) describe the Sideral and Synodic periods; (4) analyze the construction of the lunar calendar system and the hisab-rukyat mechanism; and (5) analyze the occurrence of eclipses. The uniqueness of the module is shown in the tadabbur corner which explains models of science-Islam integration for each indicator, whether they are inspirational, confirmatory, or empirical dogma. This module has been assessed as very valid from the material aspect, valid from the media aspect, and very good from user responses.
\end{abstract}

Keywords: the earth and space science module, earth-moon system, science-islam integration, preservice science teacher

\begin{abstract}
ABSTRAK
Penelitian ini bertujuan mendeskripsikan pengembangan modul IPBA materi Sistem Bumi-Bulan berbasis integrasi Sains-Islam bagi calon guru IPA di PTKI. Prosedur pengembangan dijalankan dengan mengadopsi model $4 \mathrm{D}$ (define, design, develop, dan disseminate) oleh Thiagarajan di mana tahap disseminate tidak dijalankan. Subjek pengembangan melibatkan 87 mahasiswa calon guru IPA di salah satu PTKI. Studi ini telah menghasilkan indikator modul ajar sebagai berikut: dengan menelaah ayat-ayat kauniyah dan hadits-hadits yang shahih, mahasiswa mampu (1) mengemukakan informasi-informasi faktual dan aktual tentang keadaan Bulan sebagai satelit Bumi; (2) menganalisis gerakan relatif Bulan dan fase-fase Bulan; (3) menjelaskan periode Sideral dan Periode Sinodik; (4) menganalisis konstruksi sistem kalender Bulan dan mekanisme hisab-rukyat; dan (5) mampu menganalisis terjadinya gerhana. Keunikan modul ditunjukkan melalui pojok tadabbur yang menerangkan model integrasi sains-Islam pada masing-masing indikator, baik yang bersifat inspirasi, konfirmasi, dan dogma empiris. Modul ini telah dinilai sangat valid dari aspek materi, valid dari aspek media, dan sangat baik dari respons pengguna.
\end{abstract}

Kata kunci: modul IPBA, sistem Bumi-Bulan, integrasi sains-Islam, calon guru IPA

\section{PENDAHULUAN}

Kebangkitan sains dalam dunia Islam telah dipopulerkan oleh seorang muslim pemenang Nobel Fisika, yakni Muhammad Abdus Salam (Salam \& Dalafi, 1994). Meski tidak selalu menggunakan kata "integrasi" secara eksplisit, di kalangan Muslim modern gagasan tentang perlunya integrasi 
sains dan agama, atau akal dan wahyu (keimanan), telah lama beredar. Nama-nama yang sering muncul dalam pembahasan ini adalah Syed Muhammad Naquib Al-Attas, Isma'il Al-Faruqi, dan Ziauddin Sardar (Bagir, 2005). Al-Attas menyebut ide aslinya sebagai "dewesternization of science”, Isma'il Al-Faruqi menjelaskan Islamisasi Ilmu; sedangkan Sardar mengusung gagasan sains-Islam kontemporer". Di samping itu, Mehdi Golshani, seorang Fisikawan, yang pada 1980an populer dengan karyanya "The Holy Qur'an and Sciences of Nature" menandai awal upayanya untuk mengintegrasikan sains dengan Islam (Muslih, 2010). Agus Purwanto, seorang fisikawan Indonesia yang aktif menyuarakan konsep integrasi sains-Islam melalui karyanya "Ayat-Ayat Semesta" dan "Nalar Ayat-Ayat Semesta", menyebutkan bahwa Al-Qur'an memiliki posisi penting dalam basis pengembangan ilmu pengetahuan (Purwanto, 2008, 2015).

Dalam konteks Indonesia, perubahan Perguruan Tinggi Keagamaan Islam/PTKI (Institut Agama Islam Negeri / Sekolah Tinggi Agama Islam Negeri (IAIN / STAIN) menjadi Universitas Islam Negeri (UIN)) menjadikan PTKI mengemban amanat yang lebih luas, baik dalam pengembangan ilmu agama maupun ilmu umum. Di samping itu, kebutuhan akan studi terhadap sains-sains Islam merupakan pemicu utama bagi kajian integrasi sains dan agama di PTKI (Minhaji, 2004). Dalam konteks Kurikulum 2013 yang diterapkan pada Kurikulum Nasional, keterkaitan ilmu pengetahuan dan agama diwujudkan dalam Kompetensi Inti (KI 1) pertama, Kompetensi Inti (KI) dirancang dalam empat kelompok yang saling terkait menyangkut sikap beragama (KI 1), sikap sosial (KI 2), ilmu (KI 3), dan penerapan ilmu (KI 4). Keempat kelompok tersebut menjadi acuan Kompetensi Dasar (KD) dan harus dikembangkan dalam setiap kegiatan pembelajaran secara terintegrasi. Kompetensi yang terkait dengan sikap religius dan sosial dikembangkan secara tidak langsung ketika peserta didik mempelajari pengetahuan (KI 3) dan penerapan pengetahuan (KI 4) (Badan Penelitian dan Pengembangan, 2013).

Keberadaan Program Studi Tadris / Pendidikan Ilmu Pengetahuan Alam (IPA) di PTKI merupakan salah satu implikasi dari perubahan status PTKI tersebut. Program studi Tadris IPA memiliki visi melahirkan pendidik profesional dalam bidang IPA yang berwawasan nilai-nilai keislaman. Unsur keislaman inilah yang menjadi pembeda sekaligus keunggulan program studi Tadris IPA dari PTKI dengan dari perguruan Tinggi Umum (PTU). Di sisi lain, internalisasi nilainilai keislaman dalam unsur-unsur program studi IPA, khususnya pada mata-mata kuliah bidang IPA menjadi tantangan tersendiri. Berbagai model pengintegrasian unsur-unsur Islam dalam matamata kuliah bidang IPA telah diusulkan oleh beberapa peneliti. Imaduddin (2020) mengusulkan konsep Islamic-Science, Environment, and Technology (I-SETS) untuk mempromosikan Islamisasi sains bagi calon guru IPA. Saputro (2019) mengembangkan model manajemen pembelajaran mata kuliah tafsir sains terpadu bagi Program Studi Tadris IPA.

Menyandingkan antara sains dan Islam tidak sederhana karena keduanya berada dalam domain yang berlawanan namun disatukan. Secara metodologi, sains hanya menerima hal-hal yang bersifat logis dan empiris, tidak mengakui wahyu sebagai sumber pengetahuan, bahkan menghilangkan peran Tuhan dalam menjelaskan cara kerja alam. Sementara Islam bersifat dogmatis (sebagaimana sifat agama), bergantung pada wahyu/dalil, mengakui keberhasilan doa, dan mengakui peran Tuhan sebagai Sang Pencipta dan Pengatur alam semesta. Jika sementara ditemukan antara ketentuan sains dan Islam bertentangan, maka ketentuan Islam merupakan pilihan mutlak bagi orang yang beriman. Namun sains dan Islam memiliki kesamaan, yakni terdapat aktivitas observasi, eksperimen, dan analisis terhadap alam (Purwanto, 2008). Berbagai ayat Al-Qur'an menyebutkan perintah untuk melakukan pengamatan (QS Al-Mulk [67]:3-4, Luqman: 29, Al Ghasyiyah: 17-20, QS Saba' [34]: 9, dsb), mengajukan pertanyaan (Al-Baqarah [2]: 189, An Nahl [16]: 43, dsb), analisis/perenungan terhadap alam (QS Ali Imran [3]: 190-191, Al Baqarah [2]: 164, dsb) sebagaimana metode ilmiah pada umumnya, namun berujung pada penyerahan diri kepada Sang Pencipta. Purwanto (2008) menambahkan, Al-Qur'an mengandung 800 ayat kauniyah (ayat-ayat tentang alam) yang jumlahnya melebihi ayat fikih, yang layak menjadi kajian penelitian dan pengajaran di bidang IPA. 
Berbicara tentang memasukkan integrasi sains-Islam dalam mata kuliah IPA, penulis memusatkan pembahasan ini pada mata kuliah Ilmu Pengetahuan Bumi dan Antariksa (IPBA). Mata kuliah ini merupakan mata kuliah wajib pada program studi pendidikan IPA. Mata kuliah ini membahas tentang beragam fakta, konsep, prinsip, dan prosedur dalam eksplorasi kebumian dan antariksa, dengan kompetensi minimal dapat membelajarkan materi-materi yang relevan di tingkat sekolah menengah (SMP/MTs). Mata kuliah IPBA dipilih karena dinilai yang paling strategis dalam mengimplementasikan model integrasi sains-Islam (Fajar dkk., 2016). Di samping karena banyak ayat Al-Qur'an yang menyebutkan objek-objek kebumian dan antariksa, mata kuliah ini menyajikan analisis fenomena kebumian dan antariksa berdasarkan prosedur ilmiah seperti pada umumnya. Namun sisi khasnya adalah domain sains dan domain keislaman dapat saling berdialog.

Pada studi ini, penulis memilih fokus analisis pada materi Sistem Bumi-Bulan. Materi ini menjelaskan keberadaan Bulan sebagai satelit Bumi beserta dampak-dampak gerakan Bulan terhadap kehidupan di Bumi (misalnya kenampakan fase-fase Bulan, sistem kalender Bulan, gerhana, dan pasang surut air laut). Salah satu model integrasi sains-Islam dalam materi Sistem Bumi-Bulan ditampilkan pada pembahasan konstruksi Sistem Kalender Bulan/Qamariyah. Perumusan sistem kalender ini didasarkan pada pengamatan empiris, analisis data, dan deduksi terhadap gerakan relatif Bulan, Bumi, dan Matahari yang bersumber dari hadits shahih dan ayat kauniyah di dalam Al-Qur'an.

"Berpuasalah karena melihatnya (bilal Ramadhan) dan berbukalah karena melihatnya (bilal Syawal), jike berawan (tidak bisa melibatnya) maka sempurnakanlah bitungan bulan Sya'ban menjagi tiga puluh (30)." (HR Muslim no. 1081 dan an-Nasa i no. 2124)

"Dan matahari berjalan ditempat peredarannya. Demikianlah ketetapan Yang Maha Perkasa lagi Maha Mengetahui. Dan telah Kami tetapkan bagi bulan manzilah-manzilah, sehingga (setelah dia sampai ke manzilah yang terakhir) kembalilah dia sebagai bentuk tandan yang tua. Tidaklah mungkin bagi matahari mendapatkan bulan dan malam pun tidak dapat mendabului siang. Dan masing-masing beredar pada garis edarnya." (QS Ya Sin [36]: 38-41)

\section{"Matabari dan bulan (beredar) menurut perbitungan." (QS Ar-Rahman [55]: 5)}

Ayat-ayat di atas merupakan sebagian dalil yang menginspirasi integrasi sains-Islam (dengan contoh konkret yaitu perkembangan iptek tentang hisap dan rukyat (ilmu falak)), yakni ilmu pengetahuan alam yang didukung, dieksplorasi, dan dikembangkan berdasarkan sumbersumber Ilahiyah (Al-Qur'an dan Hadits) (Thoyib, 2013). Dalam studi ini, terdapat beberapa pokok pengintegrasian sains-Islam yang diajarkan pada mata kuliah IPBA materi Sistem Bumi-Bulan yang dikemas melalui modul ajar materi Sistem Bumi-Bulan.

Modul ajar memiliki peran yang sangat penting dalam pembelajaran. Modul merupakan suatu bahan ajar yang bersifat singkat dan spesifik untuk suatu tujuan pembelajaran, berisi rangkaian kegiatan pembelajaran yang terorganisasi, dan memuat materi dan evaluasi (Lasmiyati \& Harta, 2014). Modul berperan utama dalam menunjang pembelajaran baik secara bersama-sama di dalam kelas maupun secara mandiri (Mardia \& Sundara, 2020; Rahayu \& Sudarmin, 2015).

Berdasarkan analisis penulis, pengembangan modul dengan basis integrasi sains-Islam telah banyak diteliti di Indonesia. Prihandoko, dkk (2020) berhasil mengembangkan modul IPA terintegrasi Al-Qur'an dan Hadits bagi siswa SMP untuk meningkatkan karakter religius. Latifah (2015) berhasil mengembangkan modul terintegrasi ayat-ayat Al-Qur'an dengan tema air sebagai sumber kehidupan pada mata pelajaran IPA SMP. Syafitri dan Darmana (2018) mengintegrasikan nilai-nilai Islam pada modul kimia SMA materi termokimia dan laju reaksi. Aditia dan Muspiroh (2013) berhasil mengembangkan dan mengimplementasikan modul Sains, Lingkungan, Teknologi, Masyarakat dan Islam (Salingtemasis) untuk meningkatkan hasil belajar siswa pada konsep ekosistem kelas X SMA. Modul IPA terintegrasi sains-Islam juga dilaporkan dapat meningkatkan literasi keislaman bagi siswa SMA (Diani dkk., 2019), dan keterampilan berpikir kritis bagi siswa 
MI (Khairiyah \& Faizah, 2019). Penekanan pada peta konsep di dalam modul sains-Islam dilaporkan oleh Sintia dan Violita (2020). Dari tinjauan tersebut, sebagian besar modul sains-Islam yang dikembangkan oleh berbagai peneliti ditujukan untuk siswa sekolah (SD s/d SMA) dan belum ditemukan penelitian tentang pengembangan modul sains-Islam bagi calon guru IPA, khususnya pada mata kuliah IPBA materi Sistem Bumi-Bulan. Sementara itu, calon guru IPA dari PTKI mengemban amanah untuk mempromosikan integrasi sains-Islam pada mata pelajaran IPA untuk kemajuan ilmu dan agama.

Berdasarkan uraian tersebut, tulisan ini bertujuan mendeskripsikan hasil pengembangan modul IPBA materi Sistem Bumi-Bulan berbasis integrasi Sains-Islam bagi calon guru IPA di PTKI. Fitur-fitur khas dalam model pengintegrasian akan dilaporkan dalam tulisan ini. Harapan penulis, hasil pengembangan dapat menjadi rujukan bagi penelitian tentang integrasi sains-Islam dalam cakupan yang lebih luas.

\section{METODOLOGI}

Jenis Penelitian. Studi yang telah dilaporkan dalam tulisan ini merupakan penelitian dan pengembangan (Research and Development/RnD) yang bertujuan menghasilkan modul Sistem BumiBulan dengan basis integrasi sains-Islam bagi calon guru IPA di PTKI yang teruji validitasnya, kemenarikannya, dan kelayakannya. Penulis menggunakan model pengembangan 4D (Define, Design, Develop, dan Disseminate) oleh Thiagarajan (1974) di mana tahap Disseminate tidak dijalankan.

Prosedur Pengembangan. Pada tahap Pendefinisian (Define), penulis melakukan analisis kebutuhan yang dirinci menjadi analisis pembelajar, analisis kurikulum, dan spesifikasi tujuan pembelajaran. Pada tahap Perancangan (Design), penulis melakukan pembuatan modul dengan memperhatikan spesifikasi dan keunikan modul. Pada tahap Pengembangan (Develop), modul yang sudah dihasilkan diberikan penilaian oleh validator (expert appraisal) dan respons pengguna (developmental testing).

Subjek Pengembangan. Produk pengembangan diberikan penilaian oleh beberapa validator. Validator materi antara lain 1 dosen Ilmu Falak pada Fakultas Syarian IAIN Jember, 1 dosen studi Islam pada STAI Al Hikam Malang, dan 1 dosen IPBA dari Universitas Islam Lamongan. Validator media yakni 2 dosen media pembelajaran dari IAIN Jember. Selain penilaian dari para pakar, penelitian ini juga menggali respons pengguna, yakni 87 mahasiswa Tadris IPA IAIN Jember semester 3 yang menempuh mata kuliah IPBA.

Instrumen penilaian. Instrumen penilaian berupa lembar angket yang diberikan kepada validator dan pengguna. Skor diberikan berdasarkan skala Likert: SS/sangat setuju (4), S/setuju (3), TS/tidak setuju (2), dan STS/sangat tidak setuju (1). Penilai juga dapat memberikan komentar secara kualitatif pada angket. Kisi-kisi instrumen validasi materi, validasi media, dan respons pengguna berturut-turut ditampilkan pada Tabel 1, Tabel 2, dan Tabel 3.

Tabel 1. Kisi-Kisi Instrumen Validasi Materi

\begin{tabular}{cllc}
\hline No & Aspek penilaian & \multicolumn{1}{c}{ Indikator } & Jumlah butir \\
\hline 1 & Kelayakan isi & $\begin{array}{l}\text { Kebenaran substansi materi, manfaat untuk penambahan } \\
\text { wawasan, relevansi dengan kebutuhan mahasiswa, kesesuaian } \\
\text { dengan tujuan, relevansi (ilustrasi gambar, tugas, kuis) }\end{array}$ & 12 \\
\hline 2 & Kelayakan bahasa & $\begin{array}{l}\text { Keterbacaan, kejelasan infromasi, kesesuaian dengan kaidah } \\
\text { bahasa, efektivitas dan efisiensi kalimat }\end{array}$ & 5 \\
\hline 5 & Kelayakan penyajian & $\begin{array}{l}\text { Sistematika, komunikatif, kelengkapan informasi, pemberian } \\
\text { motivasi, stand alone }\end{array}$ & 7 \\
\hline
\end{tabular}


Tabel 2 Kisi-Kisi Instrumen Validasi Media

\begin{tabular}{cllc}
\hline No & \multicolumn{1}{c}{ Aspek penilaian } & \multicolumn{1}{c}{ Indikator } & $\begin{array}{c}\text { Jumlah } \\
\text { butir }\end{array}$ \\
\hline 1 & Kelayakan desain & $\begin{array}{l}\text { Komposisi warna, lay-out, sinkronisasi antara ilustrasi grafis } \\
\text { dengan visual dan verbal, kemenarikan, kejelasan judul. }\end{array}$ & 6 \\
\hline 2 & $\begin{array}{l}\text { Kelayakan kemudahan } \\
\text { penggunaan }\end{array}$ & Kelengkapan fitur, sistematika penyajian & 4 \\
\hline 3 & Kelayakan konsistensi & $\begin{array}{l}\text { Konsistensi penggunaan kata/istilah, konsistensi font, } \\
\text { konsistensi lay out }\end{array}$ & 3 \\
\hline 4 & $\begin{array}{l}\text { Kelayakan } \\
\text { Kemanfaatan }\end{array}$ & $\begin{array}{l}\text { Menarik fokus pengguna, aplikatif, mempermudah } \\
\text { pembelajaran }\end{array}$ & 6 \\
\hline 5 & Kelayakan Kegrafikan & Font, ilustrasi, warna & 5 \\
\hline
\end{tabular}

Tabel 3 Kisi-Kisi Instrumen Respons Pengguna

\begin{tabular}{cllc}
\hline No & \multicolumn{1}{c}{ Aspek penilaian } & \multicolumn{1}{c}{ Indikator } & Jumlah butir \\
\hline 1 & Kelayakan isi & $\begin{array}{l}\text { Kejelasan tujuan, kesesuaian materi dengan tujuan, urutan } \\
\text { materi, relevansi praktik dan kuis }\end{array}$ & 8 \\
\hline 2 & Kelayakan kebahasaan & $\begin{array}{l}\text { Kejelasan kalimat, pemilihan istilah, penggunaan bahasa yang } \\
\text { komunikatif }\end{array}$ & 6 \\
\hline 3 & Kelayakan kemanfaatan & $\begin{array}{l}\text { Mempunyai daya tarik, mempermudah dalam pembelajaran } \\
\text { bersama-sama maupun mandiri, mengandung motivasi, } \\
\text { aplikatif }\end{array}$ & 7 \\
\hline 4 & Kelayakan kegrafikan & $\begin{array}{l}\text { Pemilihan font, estetika desain dan lay out, kualitas gambar } \\
\text { dan ilustrasi }\end{array}$ & 6 \\
\hline
\end{tabular}

Teknik analisis data. Analisis data dilakukan secara kuantitatif dan kualitatif. Analisis secara kuantitatif digunakan untuk menentukan skor hasil penilaian. Rumus yang digunakan dituliskan pada Persamaan (1) merujuk pada Akbar (2013) dengan kategori skor hasil penilaian dijelaskan pada Tabel 4. Analisis kualitatif digunakan untuk menelaah komentar, saran, dan kritik dari para penilai dan pengguna.

$$
\text { Skor Penilaian }(X)=\frac{\text { Skor per item }}{\text { Skor ideal }} \times 100 \%
$$

\section{Tabel 4 Kriteria Skor Penilaian}

\begin{tabular}{cl}
\hline Skor Penilaian $(\mathrm{X})$ & \multicolumn{1}{c}{ Kriteria } \\
\hline $85,01 \%-100 \%$ & Sangat baik/valid, atau dapat digunakan tanpa revisi \\
\hline $70,01 \%-85 \%$ & Cukup baik/valid, atau dapat digunakan namun perlu direvisi kecil \\
\hline $50,01 \%-70 \%$ & Kurang baik/valid, disarankan tidak dipergunakan karena perlu revisi besar \\
\hline $1 \%-50 \%$ & Tidak baik/valid atau tidak boleh dipergunakan \\
\hline
\end{tabular}

\section{TEMUAN DAN PEMBAHASAN}

Hasil pengembangan modul IPBA materi Sistem Bumi-Bulan berbasis integrasi sainsIslam dideskripsikan sebagai berikut: 


\section{Pendefinisian (Define)}

Tahap pendefinisian (Define) mendeskripsikan analisis kebutuhan pengembangan modul Sistem Bumi Bulan yang dirinci melalui analisis pembelajar, analisis kurikulum, dan spesifikasi tujuan pembelajaran.

Analisis Pembelajar. Penelitian ini telah dimulai dengan menganalisis karakteristik pengguna modul pembelajaran Sistem Bumi-Bulan. Sasaran modul adalah mahasiswa calon guru IPA semester 3 di perguruan tinggi keagamaan Islam. Berdasarkan survey terhadap 87 mahasiswa, diketahui bahwa: 65,9\% merupakan lulusan Madrasah Aliyah (MA), 58,8\% merupakan lulusan pondok pesantren, dan 29,4\% sedang berkuliah sambil menempuh pendidikan di pondok pesantren. Data ini menyimpulkan bahwa sebagian besar mahasiswa memiliki latar belakang keislaman yang kuat. Dengan karakteristik tersebut, mahasiswa calon guru IPA dari PTKI mengemban amanah untuk mampu mengajarkan mata pelajaran IPA terintegrasi penjelasan ayatayat kauniyah dan hadits shahih dengan konsep pengintegrasian yang tepat.

Sementara itu, analisis terhadap kemampuan akademik mahasiswa yang telah menempuh mata kuliah IPBA selama 4 tahun terakhir masih dalam rentang nilai 70-79 (baik), namun ada kecenderungan besar untuk menuju rentang 60-69 (cukup). Survey juga menunjukkan motivasi belajar mahasiswa termasuk kategori baik. Dengan demikian, diperlukan berbagai upaya untuk meningkatkan kompetensi akademik mahasiswa dan motivasi belajarnya, khususnya pada mata kuliah IPBA. Salah satunya melalui pembelajaran dengan modul.

Analisis Kurikulum. Program studi Tadris / Pendidikan IPA di PTKI memiliki kekhasan kurikulum yakni menyuguhkan mata kuliah rumpun IPA/ilmu umum dan rumpun ilmu keislaman dalam waktu yang bersamaan. Manfaat yang dapat diperoleh adalah kedua rumpun ilmu tersebut dapat saling berdialog. Salah satunya adalah mata kuliah IPBA yang berdampingan dengan mata kuliah Ulumul Quran, Ulumul Hadits, maupun Ilmu Tafsir. Berdasarkan tinjauan terhadap Rencana Pembelajaran Semester (RPS) mata kuliah IPBA Program Studi Tadris IPA IAIN Jember, salah satu capaian pembelajarannya adalah mahasiswa mampu menganalisis gerakan relatif bulan dan pengaruhnya terhadap kehidupan di bumi. Hal ini telah bersesuaian dengan KD IPA SMP pada kurikulum 2013 (yakni pada KD 3.11 dan KD 4.11).

Di samping itu, beberapa penelitian melaporkan bahwa pembelajaran IPBA (khususnya astronomi) di sekolah-sekolah dan di perguruan tinggi belum menyelenggarakan kegiatan laboratorium (Pujani, 2015; Pujani \& Suma, 2020). Oleh karena itu, perlu dikembangkan kegiatan praktikum yang relevan dengan materi Sistem Bumi-Bulan di dalam modul, khususnya yang berkaitan dengan integrasi sains Islam.

Analisis kurikulum juga telah mengeksplorasi ayat-ayat kauniyah dan hadits-hadits shahih yang berkaitan materi Sistem Bumi-Bulan sebagaimana yang dirinci pada Tabel 5. Sebagai target pembelajaran, penulis menggunakan istilah tadabbur yang bermakna memikirkan dan merenungkan ayat-ayat al-Qur'an agar dapat memahaminya, menyelami makna dan hikmah-hikmahnya serta mengetahui kandungannya (Maya, 2017).

Spesifikasi tujuan pembelajaran. Berdasarkan analisis terhadap kurikulum mata kuliah IPBA tentang Sistem Bumi-Bulan dengan basis integrasi sains-Islam, maka penulis merumuskan indikator pembelajaran sebagai dasar pengembangan modul sebagai berikut: Dengan menelaah ayat-ayat kauniyah dan hadits-hadits shahih, mahasiswa mampu (1) mengemukakan informasiinformasi faktual dan aktual tentang keadaan Bulan sebagai satelit Bumi; (2) menganalisis gerakan relatif Bulan dan fenomena fase-fase Bulan; (3) menjelaskan periode Sideris dan Periode Sinodis; (4) menganalisis konstruksi sistem kalender Bulan dan mekanisme hisab-rukyat; (5) menganalisis fenomena gerhana; dan (6) menjelaskan terjadinya pasang surut air laut akiba gerakan Bulan. 
Tabel 5 Analisis Dalil dan Kaitannya dengan Materi Sistem Bumi-Bulan

\begin{tabular}{|c|c|c|}
\hline No & Dalil & Tadabbur \\
\hline 1 & $\begin{array}{l}\text { Al-Qamar [54]: } 1 \\
\text { HR Bukhari no. } 3364\end{array}$ & Keadaan Bulan yang pernah terbelah pada zaman Rasulullah \\
\hline 2 & $\begin{array}{l}\text { QS Yunus [10]: } 5 \\
\text { QS Nuh [71]: } 16 \\
\text { QS Al-Furqan [25]: } 61 \\
\text { QS Ya Sin [36]: 38-40 } \\
\text { QS Qaf [50]: 39 }\end{array}$ & $\begin{array}{l}\text { Bulan tidak memancarkan cahaya sendiri, melainkan pantulan dari } \\
\text { cahaya Matahari. } \\
\text { Adanya gerak relatif antara matahari dan bulan, dari } 2 \text { hal ini } \\
\text { timbul fase-fase Bulan dan menjadi pondasi sistem Kalender } \\
\text { Qomariyah. } \\
\text { Menegaskan pentingnya waktu subuh dan magrib untuk penanda } \\
\text { ibadah dan tafakkur. }\end{array}$ \\
\hline 3 & $\begin{array}{l}\text { QS Al-Baqarah [2]: 185, } 189 \\
\text { HR Bukhari no. 1773-1778 } \\
\text { QS Ar-Rahman [33]: } 5\end{array}$ & Cara kerja hisab dan rukyat dalam sistem kalender Qomariyah \\
\hline 4 & HR Bukhari no. 982-985 & Pandangan Islam tentang fenomena gerhana \\
\hline
\end{tabular}

\section{Perancangan (Design)}

Tahap perancangan (design) merupakan tahapan pembuatan modul berdasarkan data yang diperoleh dalam tahap pendefinisian (define). Agar modul memuat penjelasan yang sistematis dan memiliki keunikan dari modul yang lain, modul ini dirancang memiliki fitur-fitur sebagai berikut: (1) Pojok Tadabbur, bagian ini merupakan tadabbur ayat-ayat kauniyah dan hadits-hadits shahih tentang materi Sistem Bumi-Bulan; (2) Materi, bagian ini merupakan materi inti sesuai dengan capaian pembelajaran yang telah dirumuskan; (3) Pengayaan - Simulasi komputer; bagian ini memaparkan kegiatan pembelajaran yang memanfaatkan aplikasi komputer atau android untuk memperjelas materi inti; (4) Pengayaan - Praktikum Lapangan, bagian ini memaparkan kegiatan praktikum di ruang terbuka sesuai dengan materi inti; (5) Evaluasi, bagian ini berisi soal yang harus dijawab untuk memantau perkembangan belajar. Evaluasi berisi soal pilihan ganda dan uraian. Kunci jawaban soal disediakan di halaman belakang.

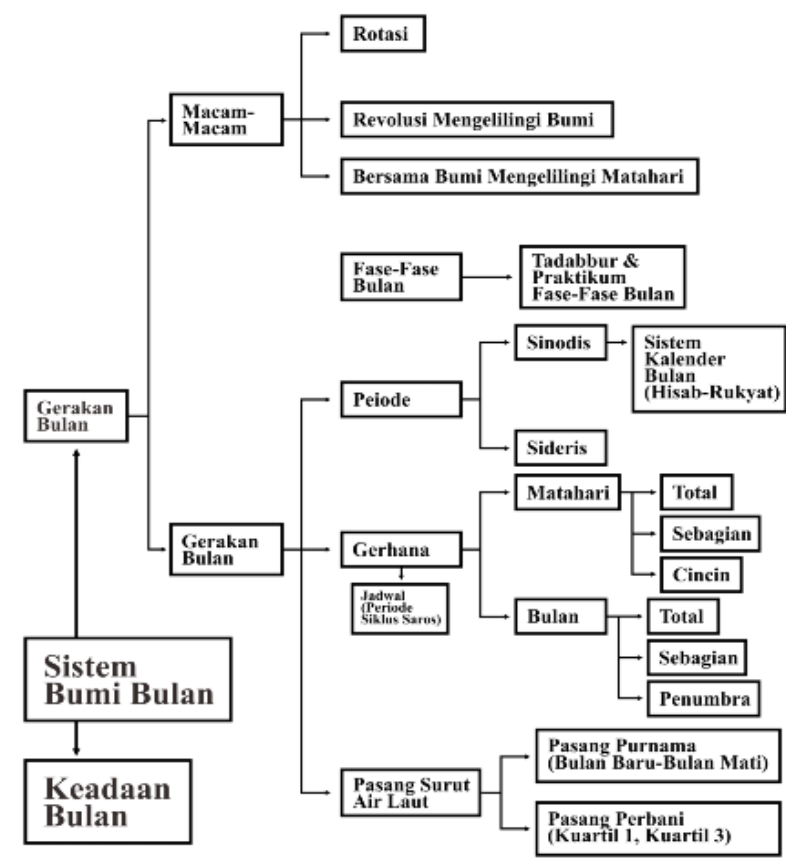

Gambar 1 Peta Konsep Modul Sistem Bumi-Bulan dengan Basis Integrasi Sains-Islam

Peta konsep materi dicantumkan di halaman depan modul sebagaimana yang ditampilkan pada Gambar 1. Keunikan modul ini ditandai dengan adanya basis integrasi sains-Islam pada beberapa sub materi. Beberapa poin keunikan dideskripsikan sebagai berikut. 
Tadabuur dalil terbelahnya Bulan. Pada modul, sub materi keadaan Bulan memaparkan tentang identitas bulan (massa, diameter, jarak), suhu, keadaan atmosfer, dan morfologi seperti adanya kawah, sungai, dan gunung di Bulan. Pada bagian ini, pengguna juga diberikan pojok taddabur berupa dalil bahwa Bulan pernah terbelah di zaman Rasulullah SAW.

Telah bercerita kepada kami Shadaqah bin Al Fadlal telah mengabarkan kepada kami Ibnu 'Uyainah dari Ibnu Abu Najih dari Mujabid dari Abu Ma'mar dari Abdullab bin Mas'ud radliallabu 'anbu berkata; Pada zaman Rasulullah shallallahu 'alaibi wasallam bulan pernah terbelab menjadi dua bagian lalu Nabi shallallabu 'alaibi wasallam bersabda: "Saksikanlab". (HR Bukhari no. 3363).

Bagian ini juga menginformasikan bahwa Rima Aiadaeus merupakan anak sungai di Bulan yang diklaim oleh umat Islam merupakan bukti mukjizat bahwa Bulan pernah terbelah pada zaman Rasulullah SAW. Namun, hingga saat ini belum ada bukti ilmiah yang menjelaskan hal ini.

Inti dari pojok tadabbur ini adalah mengimani bahwa peristiwa terbelahnya Bulan pada zaman Rasul merupakan suatu mukjizat. Sebagaimana mukjizat Nabi Ibrahim yang tidak dapat dibakar dan tongkat Nabi Musa yang berubah menjadi ular, mukjizat terbelahnya Bulan tidak harus dijelaskan secara akal, pikiran, maupun ilmu pengetahuan. Hal ini penting untuk dipaparkan di dalam modul maupun saat pembelajaran di kelas untuk menghimbau agar tidak mencocokcocokkan dalil dengan fakta-fakta sains karena saking semangatnya dalam mempromosikan integrasi sains-Islam (Saputra \& Lubis, 2018).

Fase-fase bulan. Berkaitan dengan fenomena fase-fase Bulan, pada modul dicantumkan pojok tadabbur dalil-dalil seperti pada Tabel 5 no. 2. Berikut ini ditampilkan terjemah QS Yunus [10]: 5:

Dialah yang menjadikan Matahari bersinar dan Bulan bercabaya dan ditetapkan-Nya manzilahmanzilah (tempat-tempat) bagi perjalanan Bulan itu, supaya kamu mengetabui bilangan tabun dan perbitungan (waktu). Allah tidak menciptakan yang demikian itu melainkan dengan bak. Dia menjelaskan tanda-tanda (kebesaran-Nya) kepada orang-orangyang mengetabui. QS Yunus [10]: 5

Pada QS Yunus [10]: 5, Al-Qur'an menggunakan kata “dhiya” (sinar) untuk menyebutkan cahaya matahari, dan menggunakan kata "nur" (cahaya pantulan) untuk cahaya bulan (Shihab, 1997). Ayat ini menginformasikan bahwa Matahari memancarkan sinar yang berasal dari dirinya sendiri. Sementara cahaya yang terlihat dari Bulan merupakan pantulan sinar yang dipancarkan Matahari. Inilah fakta ilmiah yang diajarkan dalam buku-buku IPA.

Pada modul, tadabbur ayat ini menginspirasi kegiatan demonstrasi penyebab fase-fase bulan menggunakan peralatan sederhana, yakni lampu sebagai matahari, bola dan pegangannya sebagai bulan, dan mata manusia sebagai bumi. Hasil demonstrasi fase-fase bulan yang ada pada modul ini telah diupload pada kanal youtube Ula Darmawan (2020). Pada penelitian yang lain, fase-fase bulan didemonstrasikan melalui kotak fase bulan (Ardiansyah, 2018).

Praktik Pengamatan Fase-Fase Bulan. Pojok tadabbur ayat-ayat pada Tabel 5 no. 2 juga memberikan petunjuk tentang kegiatan praktik pengamatan fase-fase bulan yang menjadi pondasi penanggalan sistem kalender Qomariyah.

Dan Matahari berjalan ditempat peredarannya. Demikianlah ketetapan Yang Maha Perkasa lagi Maha Mengetahui. Dan telah Kami tetapkan bagi Bulan manzilah-manzilah, sehingga (setelah dia sampai ke manzilah yang terakhir) kembalilah dia sebagai bentuk tandan yang tua. Tidaklah mungkin bagi Matahari mendapatkan Bulan dan malam pun tidak dapat mendahului siang. Dan masing-masing beredar pada garis edarnya. (QS Ya in [36]: 38-40)

Kegiatan praktikum yang terinspirasi dari ayat di atas adalah pengamatan fase, ketinggian, dan arah Bulan dari tanggal 1 hingga tanggal 29 pada penanggalan Qomariyah pada waktu subuh (pukul 04.30) dan waktu maghrib (pukul 18.30). Kedua waktu ini dipilih karena pertama Al-Qur'an banyak menjelaskan keutamaan waktu pagi dan petang ini untuk zikir, tadabbur dan tafakkur; 
kedua kedua waktu ini merupakan penanda peralihan waktu harian (siang dan malam); ketiga pada kedua waktu ini posisi matahari ditentukan dengan jelas, yakni di arah timur saat subuh, di arah barat saat maghrib. Praktikum ini merujuk pada Purwanto (2015, hlm. 398-399) dan direkomendasikan oleh Abell (2001, 2002) dan Trundle (2006) untuk mencegah miskonsepsi terhadap fase-fase bulan dan mengajarkan metode ilmiah paling sederhana sebagaimana para ilmuwan. Hasil praktikum ini mencatat ketinggian Bulan setiap hari pada tanggal bulan Qomariyah seperti pada Gambar 2.

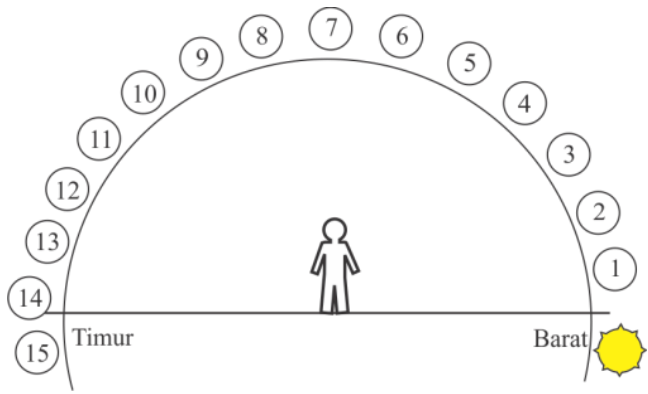

(a)

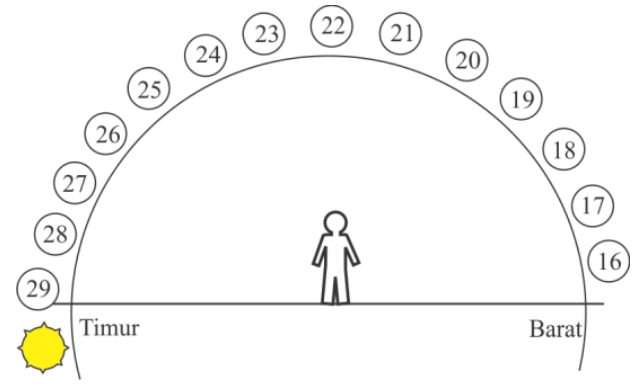

(b)

Gambar 2 Pola Harian Posisi Bulan saat (a) Maghrib (pukul 18.30) dan (b) Subuh (pukul 04.30). Angka di dalam Lingkaran Kecil Menunjukkan Tanggal Bulan Qomariyah

Gambar 2 menunjukkan ketinggian bulan yang terus berubah selama satu bulan Qomariyah yang diamati saat magrib (a) dan subuh (b). Fase bulan juga berubah mulai dari sabit paling kecil (hilal) pada tanggal 1 hingga terus membesar hingga bulan purnama pada tanggal 15, lalu kembali mengecil hingga menjadi sabit pada tanggal 29. Kesesuaian antara fase, ketinggian, dan arah menjadi indikator penentuan tanggal. Misalnya, bila Bulan teramati di arah timur ketika magrib, maka dapat diprediksi pada saat itu adalah tanggal 14/15 dan Bulan dalam fase Bulan purnama. Contoh lain, bila Bulan teramati di arah timur ketika subuh, maka dapat diprediksi bahwa saat itu adalah tanggal 27/28 dan Bulan dalam fase Bulan sabit. Pertanyaan-pertanyaan tersebut ditampilkan dalam modul pada akhir kegiatan praktikum. Pertanyaan penalaran di akhir kegiatan praktikum juga dipaparkan pada Gambar 3.

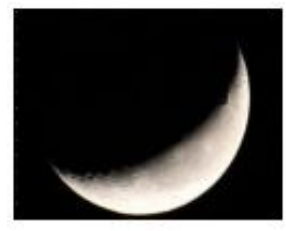

A

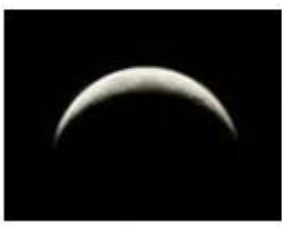

B

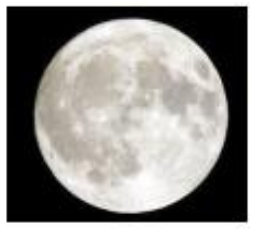

C

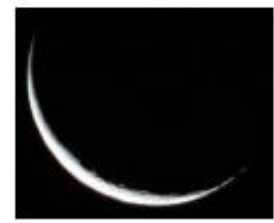

D

Gambar 3. Pertanyaan penalaran: Di antara fase-fase bulan di atas, manakah yang tidak mungkin terjadi?

Soal pada Gambar 3 mengajak mahasiswa untuk membangun kemampuan bernalarnya. Jawaban yang benar adalah B. Lengkungan Bulan berada di atas, maka Matahari berada di atas. Jika Matahari berada di atas, maka tidak mungkin malam hari (gelap) (Purwanto, 2015, hlm. 392).

Penentuan Awal Bulan Qomariyah. Sebagai dampak dari gerakan periodik Bulan, modul juga menerangkan bagaimana mekanisme hisab dan rukyat untuk penentuan awal Bulan di Indonesia dengan pojok tadabbur dalil-dalil pada Tabel 5 no. 3. Pada modul juga diinformasikan tentang perbedaan momen-momen ibadah penting (awal Ramadhan, Idul Fitri, awal Dzulhijjah) oleh berbagai ormas Islam di Indonesia pada beberapa tahun belakangan dan dapat berpotensi akan terjadi lagi. Penjelasan yang keliru mengenai penyebab perbedaan ini adalah karena perbedaan metode yang digunakan (hisab dan rukyat). Alasan yang benar, perbedaan ini disebabkan oleh perbedaan kriteria yang digunakan (Muslifah, 2020). Konteks yang diterangkan di sini adalah 
perbedaan kriteria Imkan Rukyat (2-3-8) dan wujudul hilal. Contoh pertanyaan dalam modul sebagai berikut

Berikut ini adalah hasil hisab pada saat Maghrib akhir Ramadhan (29 Ramadhan), perkirakan apakah NU dan Muhammadiyah akan berbeda? (a) Bulan ternyata terbenam lebih dahulu sebelum Matahari. (b) Matahari terbenam lebih dahulu, Bulan ternyata memiliki ketinggian $1,5^{\circ}$ saat Matahari terbenam. (c) Matahari terbenam lebih dahulu, Bulan ternyata memiliki ketinggian $7^{\circ}$ saat Matahari terbenam. Gunakan kata "besok"e atau "besok lusa" untuk menjelaskan kapan Idul Fitri menurut Muhammadiyah dan NU berdasarkan hasil hisab tersebut!

Gerhana dalam Pandangan Islam. Pada pojok tadabbur tentang gerhana, Islam memandang gerhana sebagaimana disampaikan dalam HR Bukhari no. 983. Sebab munculnya hadits ini adalah ketika momen gerhana matahari.

"Sesunggubnya matahari dan bulan tidak akan mengalami gerbana disebabkan karena matinya seorang dari manusia, tetapi keduanya adalah dua tanda dari tanda-tanda kebesaran Allah. Jika kalian melihat gerhana keduanya maka berdirilah untuk shalat."

Hikmah melaksanakan shalat ketika gerhana matahari adalah untuk menghindar dari pengamatan gerhana matahari secara langsung karena sangat berbahaya bagi mata. Peristiwa gerhana merupakan bukti kepatuhan benda-benda langit terhadap ketentuan Allah (Fajar, 2019), sehingga gerak dan posisi benda langit dapat diprediksi di masa mendatang. Dalam modul maupun pembelajaran juga diterangkan bahwa Islam menolak berbagai mitos tentang gerhana (Mujab, 2016). Modul juga menerangkan kegiatan mahasiswa untuk penelusuran di situs-situs terpercaya (misalnya https://eclipse.gsfc.nasa.gov/) tentang prediksi kapan terjadinya gerhana dalam waktu dekat serta wilayah-wilayah yang dapat mengamati.

Pada akhirnya, modul Sistem Bumi-Bulan dengan basis integrasi sains-Islam berhasil disusun dengan aplikasi Ms. Word, jumlah halaman sebanyak 54, font Arial 12, dan spasi 1,5. Modul digunakan dalam pembelajaran selama 3 pekan. Beberapa tampilan modul ditunjukkan pada Gambar 4.

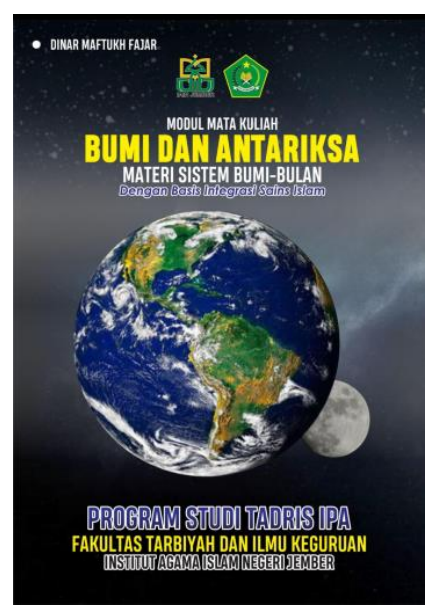

(a)

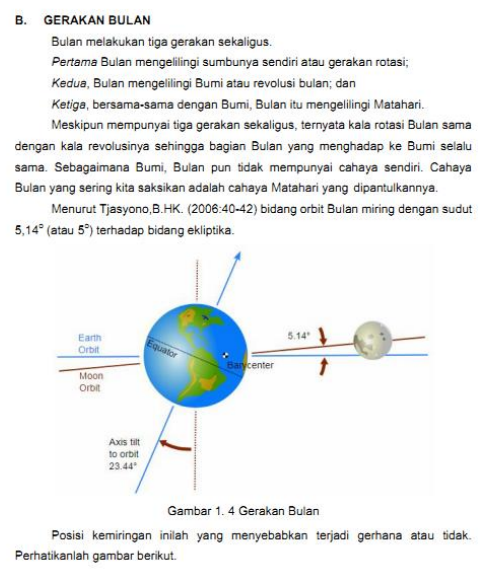

(b) 


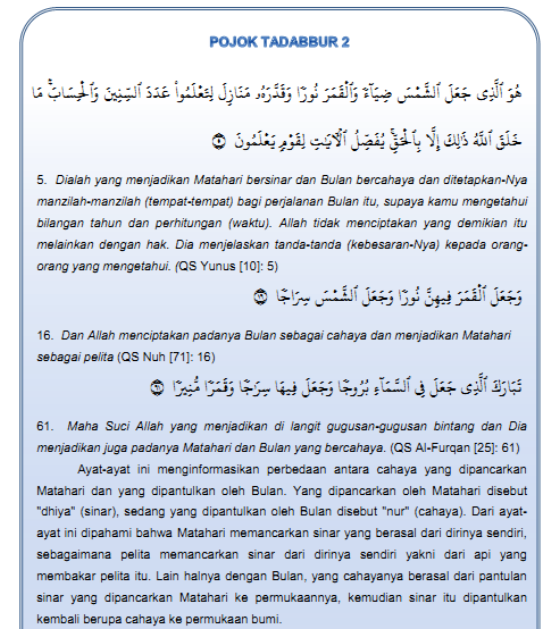

(c)
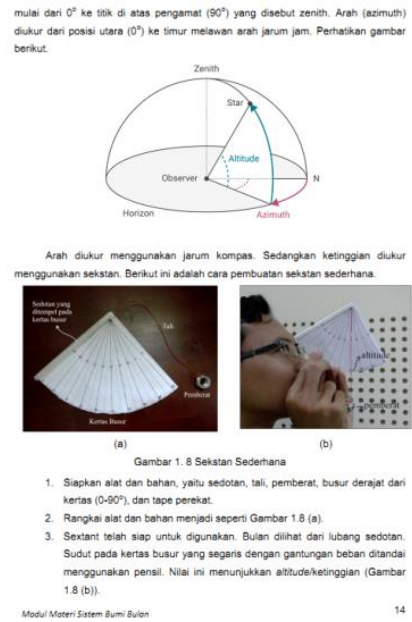

(d)

Gambar 4. Tampilan Modul: (a) Cover, (b) Materi, (c) Pojok Tadabbur, (d) Praktikum

\section{Pengembangan (Develop)}

Tahap pengembangan (Develop) merupakan tahap untuk menilai validitas modul menurut penilaian pakar $\left(V_{1}, V_{2}\right.$ dan $\left.V_{3}\right)$ dan kemenarikan modul menurut respons pengguna. Hasil penilaian dihitung menggunakan Persamaan (1) dan kriteria pada Tabel 4.

Tabel 6. Hasil Penilaian Materi

\begin{tabular}{|c|c|c|c|c|c|c|}
\hline \multirow{2}{*}{$\begin{array}{r}\text { No } \\
1\end{array}$} & Aspek penilaian & \multicolumn{4}{|c|}{ Persentase Skor } & Kategori \\
\hline & Kelayakan isi & $82,1 \%$ & $86,0 \%$ & $87,2 \%$ & $85,1 \%$ & Sangat valid \\
\hline 2 & Kelayakan bahasa & $85,5 \%$ & $\mathrm{~V}_{1}$ & $\mathrm{~V}_{2}$ & $\mathbf{V}_{3}$ & Rata-Rata \\
\hline 3 & Kelayakan penyajian & $83,4 \%$ & $85,1 \%$ & $89,8 \%$ & $86,1 \%$ & Sangat valid \\
\hline \multicolumn{2}{|c|}{ Rata-Rata } & $83,7 \%$ & $85,4 \%$ & $88,4 \%$ & $85,8 \%$ & Sangat valid \\
\hline
\end{tabular}

Tabel 7. Hasil Penilaian Media

\begin{tabular}{llrrrl}
\hline \multirow{2}{*}{ No } & \multirow{2}{*}{ Aspek penilaian } & \multicolumn{3}{c}{ Persentase Skor } & \multirow{2}{*}{ Kategori } \\
\cline { 3 - 5 } & & $\mathbf{V}_{\mathbf{1}}$ & $\mathbf{V}_{\mathbf{2}}$ & Rata-Rata & \\
\hline 1 & Kelayakan desain & $85,0 \%$ & $87,4 \%$ & $86,2 \%$ & Sangat valid \\
2 & Kelayakan kemudahan penggunaan & $81,0 \%$ & $80,3 \%$ & $80,7 \%$ & Valid \\
3 & Kelayakan konsistensi & $82,2 \%$ & $84,9 \%$ & $83,6 \%$ & Valid \\
4 & Kelayakan Kemanfaatan & $84,2 \%$ & $86,6 \%$ & $85,4 \%$ & Sangat valid \\
5 & Kelayakan Kegrafikan & $83,3 \%$ & $85,1 \%$ & $84,2 \%$ & Valid \\
\hline & Rata-Rata & $83,1 \%$ & $84,9 \%$ & $84,0 \%$ & Valid \\
\hline
\end{tabular}

Tabel 8. Hasil Respons Pengguna

\begin{tabular}{clcl}
\hline No & Aspek penilaian & Persentase Skor & Kategori \\
\hline 1 & Kelayakan isi & $89,2 \%$ & Sangat baik \\
2 & Kelayakan kebahasaan & $87,2 \%$ & Sangat baik \\
3 & Kelayakan kemanfaatan & $88,0 \%$ & Sangat baik \\
4 & Kelayakan kegrafikan & $90,8 \%$ & Sangat Baik \\
\hline \multicolumn{2}{l}{ Rata-Rata } & $88,8 \%$ & Sangat baik \\
\hline
\end{tabular}


Berdasarkan hasil pada Tabel 6, rata-rata penilaian materi pada modul diperoleh sebesar $85,8 \%$ dengan kategori sangat valid. Hasil tersebut bersesuaian dengan rata-rata penilaian pengguna pada Tabel 8 sebesar 88,8\% dengan kategori sangat baik/menarik. Aspek kelayakan isi dan kebahasaan dari kedua penilaian memiliki kesesuaian pada hasil penilaian. Namun, penilaian media pada Tabel 7 memperoleh rata-rata skor 84,9\% dengan kategori valid dengan beberapa catatan revisi dari para validator, misalnya saran untuk mendesain modul dengan aplikasi lain selain Ms. Word yang memiliki fitur yang lebih lengkap dan sesuai untuk pengembangan modul. Peta konsep juga disarankan untuk ditambahkan penjelasan pada masing-masing garis.

Validator materi menilai bahwa konten modul sudah bagus, namun untuk diterapkan dalam pembelajaran, diperlukan pembimbingan yang relatif lebih banyak dari dosen. Beberapa konten relatif baru dan dinilai tidak mudah dimengerti oleh mahasiswa. Hal ini juga dikonfirmasi oleh mahasiswa setelah diberikan survey untuk memilih konten-konten di dalam modul yang sulit dipahami. Sebesar 62,4\% memilih penentuan awal bulan Qomariyah (menurut NU dan Muhammadiyah) dinilai paling sulit dipahami. Sementara konten-konten yang lain dipilih kurang dari $30 \%$.

Hasil survey juga telah mengetahui konten materi yang membuat mahasiswa tertarik pada model integrasi sains-Islam di dalam modul. Terbelahnya Bulan pada zaman Rasul dipilih sebanyak $60 \%$, terjadinya fase-fase Bulan dilipih sebanyak 49,4\%, tinjauan gerhana dalam Islam dipilih sebanyak 47,1\%, dan penentuan awal bulan Qomariyah dipilih sebanyak 37,6\%.

Minarno (2017) dan Ahmad, dkk (2020) menganalisis bahwa peran Al-Qur'an dalam konsep integrasi sains-Islam ialah sebagai inspirasi, konfirmasi dan dogma-empiris. Pada peran inspirasi, tadabbur terhadap ayat-ayat Al-Qur'an diposisikan di awal kajian dan menjadi pemicu lahirnya aktivitas ilmiah. Peran inspirasi pada modul ini dicontohkan pada praktik pengamatan fase-fase bulan dan penentuan awal bulan Qomariyah. Sementara pada peran konfirmasi, setelah pada awal pembelajaran Al-Qur'an ditempatkan sebagai payung atau sumber inspirasi yang menaungi aktivitas ilmiah, maka pembahasan dalam suatu temuan dalam sains, "dikembalikan" atau dikonfirmasikan dengan Al-Qur'an. Dengan demikian, analisis dan sintesis dalam sains, tidak lepas dengan apa yang sudah terwahyukan dalam Al-Qur'an. Peran konfirmasi pada modul ini dicontohkan pada demonstrasi fase-fase bulan. Sementara pada peran dogma empiris, pembuktian ilmiah tidak diperlukan untuk menjelaskan suatu fakta sains yang sudah diwahyukan dalam AlQur'an. Fakta tersebut harus diterima sebagai bagian dari keimanan. Peran dogma empiris ditampilkan pada pembahasan terbelahnya Bulan pada zaman Rasul.

Hasil pengembangan modul ini turut mendukung akan pentingnya kehati-hatian dalam merumuskan konsep integrasi Sains-Islam sebagaimana yang disuarakan oleh berbagai peneliti (Nasukah, 2016; Permono, 2019; Saputra \& Lubis, 2018). Al-Qur'an sendiri bukanlah buku tentang ensiklopedia sains. Pengintegrasian bukanlah menyesuaikan atau menempelkan ayat-ayat Al-Qur'an dalam temuan-temuan sains (Ahmad dkk., 2020). Menjadi sangat berbahaya jika setiap temuan sains harus harus sesuai dengan Al-Qur'an atau setiap hukum maupun ajaran dalam Islam harus rasional dan ilmiah. Analisis penulis di sini, sebagaimana penelitian terdahulu, modul Sistem Bumi-Bulan dengan basis integrasi sains-Islam yang telah dikembangkan lebih bertujuan untuk meningkatkan literasi keislaman (Diani dkk., 2019), menginternalisasikan nilai-nilai keislaman dalam materi IPA (Syafitri \& Darmana, 2018), dan meneguhkan karakter religius (Prihandoko dkk., 2020) bagi mahasiswa calon guru IPA di PTKI.

\section{SIMPULAN}

Tulisan ini telah mendeskripsikan hasil pengembangan modul IPBA materi Sistem BumiBulan berbasis integrasi sains-Islam bagi calon Guru IPA di PTKI. Salah satu keunikan dari modul ini ialah terdapat pojok tadabbur yang menerangkan model integrasi sains-Islam pada masing- 
masing indikator, baik yang bersifat inspirasi, konfirmasi, dan dogma empiris. Modul ini telah dinilai sangat valid dari aspek materi, valid dari aspek media, dan sangat baik/menarik dari respons pengguna. Hasil pengembangan ini diharapkan dapat menjadi rujukan penelitian lebih lanjut tentang model integrasi sains-Islam dalam pembelajaran IPA.

\section{PENGHARGAAN}

Penulis mengucapkan terima kasih kepada Kementerian Agama Republik Indonesia yang telah mendanai penelitian ini melalui klaster Penelitian Pembinaan / Pengembangan Kualitas tahun 2019 dengan nomor registrasi 191140000020320.

\section{REFERENSI}

Abell, S., George, M., \& Martini, M. (2002). The Moon Investigation: Instructional Strategies for Elementary Science Methods. Journal of Science Teacher Education, 13(2), 85-100.

Abell, S., Martini, M., \& George, M. (2001). "That's what scientists have to do": Preservice elementary teachers' conceptions of the nature of science during a moon investigation. International Journal of Science Education, 23(11), 1095-1109. https://doi.org/10.1080/09500690010025049

Aditia, M. T., \& Muspiroh, N. (2013). Pengembangan Modul Pembelajaran Berbasis Sains, Lingkungan, Teknologi, Masyarakat dan Islam (Salingtemasis) dalam Meningkatkan Hasil Belajar Siswa pada Konsep Ekosistem Kelas X di SMA NU (Nadhatul Ulama) Lemahabang Kabupaten Cirebon. Scientiae Educatia: Jurnal Pendidikan Sains, 2(2), 127-148.

Ahmad, M., Minarno, E. B., \& Suyono, S. (2020). Kunci Tadabbbur dan Integrasi Al-Qur'an dalam Pembelajaran Biologi. BIOEDUCA: Journal of Biology Education, 2(2), 35-49.

Akbar, S. (2013). Instrumen perangkat pembelajaran. Bandung: PT Remaja Rosdakarya.

Ardiansyah, I. C. J. (2018). Pengaruh Penggunaan Media Kotak Fase Bulan Terhadap Hasil Belajar Siswa Materi Kenampakan Bentuk Bulan di Sekolah Dasar. Jurnal Penelitian Pendidikan Guru Sekolah Dasar, 6(1).

Badan Penelitian dan Pengembangan, K. P. dan K. (2013). Kompetensi Dasar Sekolah Menengah Pertama (SMP)/ Madrasah Tsanawiyah (MTs). Kementrian Pendidikan dan Kebudayaan.

Bagir, Z. A. (2005). Integrasi Ilmu dan Agama: Interpretasi dan Aksi. Mizan Pustaka.

Diani, R., Kesuma, G. C., Diana, N., Anggraini, R. D., \& Fujiani, D. (2019). The Development Of Physics Module With The Scientific Approach Based On Islamic Literacy. Journal of Physics: Conference Series, 1155(1), 012034.

Fajar, D. M. (2019). Menggapai Hikmah dalam Pembelajaran Sains. CV Lintas Nalar.

Fajar, D. M., Hasanah, R., \& Susanti, L. Y. (2016). Strategi Membelajarkan Sistem Kalender Islam Melalui Pembelajaran IPA. Seminar Nasional Pembelajaran IPA ke-1, 1, 58-67. https://doi.org/10.30870/jppi.v1i1.283

Imaduddin, M. (2020). A New Way to Promote Islamization of Science: I-SETS Design for PreService Science Teachers. Journal of Natural Science and Integration, 3(1), 1-12. 
Khairiyah, U., \& Faizah, S. N. (2019). The Effectiveness of Using the Islamic Integration Module on the Critical Thinking Ability of Madrasah Ibtidaiyah Students. Prisma Sains: Jurnal Pengkajian Ilmu dan Pembelajaran Matematika dan IP A IKIP Mataram, 7(2), 180-191.

Lasmiyati, L., \& Harta, I. (2014). Pengembangan Modul Pembelajaran untuk Meningkatkan Pemahaman Konsep dan Minat SMP. Pythagoras: Jurnal Pendidikan Matematika, 9(2), 161174.

Latifah, S. (2015). Pengembangan Modul IPA Terpadu Terintegrasi Ayat-Ayat Al-Qur'an pada Materi Air sebagai Sumber Kehidupan. Jurnal Ilmiah Pendidikan Fisika Al-Biruni, 4(2), 155164.

Mardia, A., \& Sundara, V. Y. (2020). Pengembangan Modul Program Linier Berbasis Pembelajaran Mandiri. Edumatica: Jurnal Pendidikan Matematika, 10(01), 9-18.

Maya, A. A. R. (2017). Perspektif Al-Qur 'an Tentang konsep Al-Tadabbur. Al-Tadabbur: Jurnal Ilmu Al-Qur'an dan Tafsir, 1(01).

Minarno, E. B. (2017). Integrasi Sains-Islam dan Implementasinya dalam Pembelajaran Biologi. Seminar Nasional Teknologi Informasi Komunikasi dan Industri, 664-669.

Minhaji, A. (2004). Transformasi IAIN Menuju UIN: Sebuah Pengantar. Integrasi Sains-Islam: Mempertemukan Epistemologi Islam dan Sain, ed. by M. Amin Abdullah (Yogyakarta: Pilar Religia, 2004).

Mujab, S. (2016). Gerhana; Antara Mitos, Sains, dan Islam. YUDISLA: Jurnal Pemikiran Hukum dan Hukum Islam, 5(1).

Muslifah, S. (2020). Upaya Menyikapi Perbedaan Penentuan Awal Bulan Qamariyah di Indonesia. Azimuth: Journal of Islamic Astronomy, 1(1), 74-100.

Muslih, M. (2010). Pengaruh Budaya dan AgamaTerhadap Sains Sebuah Survey Kritis. Tsaqafah, 6(2), 225-247.

Nasukah, B. (2016). Prospek Corak Penafsiran Ilmiah Al-Tafsir Al-'Ilmiy Dan Al-Tafsir Bil 'Ilmi Dalam Mengintepretasi Dan Menggali Ayat-Ayat Ilmiah Dalam Al-Qur'an. Al-Makrifat: jurnal kajian Islam, 1(2), 17-40.

Permono, A. (2019). Kritik Metodologi Penafsiran Bucaillisme atas Ayat-Ayat Sains. Jurnal Studi Ilmu-ilmu Al-Qur'an dan Hadis, 19(1), 1-20.

Prihandoko, A., Anggraito, Y. U., \& Alimah, S. (2020). The Development of Alquran and Hadith Integrated Science Module to Improve Student's Religious Character. Journal of Innovative Science Education, 9(3), 152-157.

Pujani, N. M. (2015). Pengembangan Perangkat Praktikum Ilmu Pengetahuan Bumi dan Antariksa Berbasis Kemampuan Generik Sains untuk Meningkatkan Keterampilan Laboratorium Calon Guru Fisika. JPI (Jurnal Pendidikan Indonesia), 3(2). https://doi.org/10.23887/jpi-undiksha.v3i2.4463 
Pujani, N. M., \& Suma, K. (2020). Pelatihan Pengamatan Objek Langit Malam Bagi Guru-Guru Fisika SMA di Kota Singaraja. Proceeding Senadimas Undiksha, 1199.

Purwanto, A. (2008). Ayat-Ayat Semesta. PT Mizan Publika.

Purwanto, A. (2015). Nalar Ayat-ayat Semesta: Menjadikan al-Quran sebagai Basis Konstruksi Ilmu Pengetabuan. Mizan.

Rahayu, W. E., \& Sudarmin, S. (2015). Pengembangan Modul IPA Terpadu Berbasis Etnosains Tema Energi dalam Kehidupan untuk Menanamkan Jiwa Konservasi Siswa. Unnes Science Education Journal, 4(2).

Salam, A., \& Dalafi, H. R. (1994). Renaissance of sciences in Islamic Countries. World Scientific.

Saputra, R., \& Lubis, K. R. (2018). Penerapan Epistemologi Islam pada Proses Pembudayaan Pola Pikir yang Islami bagi Scientist. Prosiding Konferensi Integrasi Interkoneksi Islam dan Sains, $1,157-161$

Saputro, B., Marjuni, K. M., Kuswaya, A., Saputra, H., \& Fadly, W. (2019). Developing Stages for the Scientific Cues Concept in the Integrated Science-Tafseer Learning Model. Jurnal Pendidikan IP A Indonesia, 8(1), 63-74.

Shihab, M. Q. (1997). Mukjizat Al-Quran: Ditinjau dari Aspek Kebahasaan, Aspek Ilmiah, dan Pemberitaan Gaib. Mizan Pustaka.

Sintia, N., \& Violita, V. (2020). The Validity of the Development of Integrated Islam and Science Learning Module completed with a Concept Map for Integrated Islamic Junior High School. International Journal of Progressive Sciences and Technologies, 24(1), 234-239.

Syafitri, A., \& Darmana, A. (2018). Development of Chemistry Module Integrated with Islamic Values in Thermochemistry and Reaction Rate for Senior High School Student. Jurnal Pendidikan Kimia, 10(3), 418-423.

Thiagarajan, S. (1974). Instructional Development for Training Teachers of Exceptional Children: A Sourcebook.

Thoyib, M. (2013). Model Integrasi Sains dan Agama dalam Perspektif JF Haught dan M. Golshani: Landasan Filosofis bagi Penguatan PTAI di Indonesia. AKADEMIKA: Jurnal Pemikiran Islam, 18(1), 1-28.

Trundle, K. C., Atwood, R. K., \& Christopher, J. E. (2006). Preservice Elementary Teachers' Knowledge of Observable Moon Phases and Pattern of Change in Phases. Journal of Science Teacher Education, 17(2), 87-101.

Ula Darmawan. (2020, November 20). Video Pembelajaran (Fase-fase Bulan dan Gerbana). https://www.youtube.com/watch? $\mathrm{v}=\mathrm{xoJ} t 08 \mathrm{JN} 1 \mathrm{hg} \&$ feature $=$ youtu.be 